2000;162(3):1102-1108.

doi:10.1164/ajrccm.162.3.9907120

7. Kloth $\mathrm{C}$, Maximilian Thaiss $\mathrm{W}$, Preibsch $\mathrm{H}$, et al. Quantitative chest CT analysis in patients with systemic sclerosis before and after autologous stem cell transplantation: comparison of results with those of pulmonary function tests and clinical tests. Rheumatology. 2016;55(10):1763-1770. doi:10.1093/rheumatology/kew259

8. Yasui $H$, Inui $N$, Furuhashi $K$, et al. Multidetector-row computed tomography assessment of adding budesonide/formoterol to tiotropium in patients with chronic obstructive pulmonary disease. Pulm Pharmacol Ther. 2013;26(3):336-341.

doi:10.1016/j.pupt.2013.01.005

\title{
PHÂN TÍCH MộT Số KỸ NĂNG THỰC HÀNH CỦA NGƯờI BÁN LẺ THUỐC TẠI CÁC NHÀ THUỐC TRÊN Đİ BÀN TỈNH VĨNH PHÚC 2020
}

\section{TÓM TẮT}

Mục tiêu nghiên cứu: phân tích về kỹ năng thực hành bán lẻ thuốc của các nhà thuốc trên đia bàn tỉnh Vĩnh Phúc năm 2020. Đối tượng: người đến mua thuốc tai các nhà thuốc đat chuân GPP trên đia bản tỉnh. Phương pháp: thiết kế nghiên cứu mô tả cắt ngang. Kết quả: có $72,12 \%$ người mua được hỏi về đối tượng dùng thuốc, 74,12\% được yêu câu mô tả về các triệu chứng bênh, tình trang bênh. Bên canh đó các câu hỏi về đơn thuốc và kiểm tra đơn thuốc còn chiếm tỷ lệ khá thấp (25,88\% và $10,09 \%)$. Việc khai thác các thông tin khác của khách hàng cũng vấn hạn chế, $25,88 \%$ khách hàng được hỏi về các thuốc đang sử dụng. Có $62,28 \%$ người mua được tư vấn về cách phòng tránh bệnh, $52,19 \%$ được tư vấn lựa chọn thuốc phù hợp với khả năng tài chính, $50,44 \%$ được tư vấn về chế độ sinh hoat, dinh dưỡng. Có $78,07 \%$ người mua được hướng dẫn sử dụng thuốc, $79,82 \%$ hướng dẫn về thời điểm dùng thuốc, 78,95\% viết hướng dẫn sử dụng thuốc lên hộp/vỉ. Kết luận: đa số khách hàng đều nhận được từ 2-3 câu hỏi, hoạt động tư vấn khách hàng được thực hiện khá đầy đủ, nhửng tỷ lệ chưa cao. Hoạt động hướng dẫn sử dụng thuốc được đa số người bán thuốc thực hiện với tỉ lê và tuần xuẩt cao nhất. Đối với các trường hợp khách hàng không có đơn thuốc, các hoạt động hỏi - tư vấn hướng dẫn có tỉ lệ cao hơn với trường hợp khách hàng có đớn.

Từ khóa: Nhà thuốc đạt GPP, kỹ năng thực hành bán lẻ thuốc.

\section{SUMMARY \\ ANALYSIS OF SEVERAL PRACTICE SKILLS OF DRUG RETAILERS AT PHARMACIES IN VINH PHUC PROVINCE IN 2020}

Purpose: Analysis of several drug retail practice skills at pharmacies in Vinh Phuc province in 2020. Objective: People who purchase drugs at GPP pharmacies in Vinh Phuc province. Method: Cross-

*Trường Đại học Dước Hà Nọi

Chịu trách nhiệm chính: Nguyễn Thị Song Hà

Email: songhaktd@gmail.com

Ngày nhận bài: 01.3.2021

Ngày phản biên khoa hoc: 21.4.2021

Ngày duyệt bài: 4.5.2021

\section{Nguyễn Thị Song Hà*}

sectional descriptive study. Results: $72.12 \%$ of buyers were asked about drug users, $74.12 \%$ of buyers were asked to describe symptoms and conditions. Additionally, the proportion of questions about prescription and prescription validation is relatively low ( $25.88 \%$ and $10.09 \%$ respectively). The exploitation of other customer information is still limited, under which only $25.88 \%$ of buyers were asked about the drugs being used. $62.28 \%$ of buyers were advised on how to prevent disease, while the ratio for buyers who were advised on the suitable drugs with their financial capacity was $52.19 \%$, and $50,44 \%$ of buyers were counseled on lifestyle and nutrition. Meanwhile, $78.07 \%$ of buyers were instructed on how to use the drugs, $79.82 \%$ of buyers were instructed about the time to use the drugs, and $78,95 \%$ of buyers were written the instructions for using the drugs on the drug boxes/blister packs. Conclusion: The majority of customers receive 2-3 questions, and although customer consultation is undertaken quite adequately, the rate is still not high. Instruction for using drugs is carried out by the majority of drug sellers with the highest rate and frequency. For customers who does not have a prescription, the rate of checking, counseling, and guidance are higher than those who have a prescription. skills.

Keywords: GPP drugstores, retail drug practice

\section{I. ĐĂT VẤN ĐỀ}

Số lượng các cơ sở bán lẻ thuốc trên đia bàn tỉnh Vĩnh Phúc trong những năm gân đây phát triển nhanh chóng, góp phẩn quan trọng trong việc đảm bảo cung ứng thuốc đến cho người dân. Nhưng đó cũng là thách thức cho các cơ quan quản lý nhà nước, liệu sự phát triển mạnh số lượng các nhà thuốc có song hành cùng với chất lượng? Các quy định của Tiêu chuẩn thực hành tốt cơ sở bán lẻ thuốc (GPP) mới ban hành sẽ được thực hiện, duy trì ra sao sau khi đơn vị bán lẻ đã được kiểm tra thẩm định, cấp giấy chứng nhận GPP? Kỹ năng thực hành tư vấn thuốc của người bán hàng ở các nhà thuốc đã tuân thủ đúng quy định và có chất lượng hay chưa?

Nghiên cứu này phân tích về kỹ năng thực 
hành bán lẻ thuốc tai các nhà thuốc trên địa bàn tỉnh Vĩnh Phúc năm 2020

\section{II. ĐỐI TƯợNG VÀ PHƯƠNG PHÁP NGHIÊN CỨU}

2.1. Đối tượng, thời gian và địa điểm nghiên cứu

- Đối tượng: Các nhà thuốc đạt tiêu chuẩn GPP trên địa bàn tỉnh Vĩnh Phúc còn hoạt động đến ngày 31 tháng 2 năm 2020[6]; Người đến mua thuốc tai các nhà thuốc.

- Thời gian: được tiến hành từ ngày 01/12/2019 đến 31/2/2020.

- Địa điểm nghiên cứu: Các nhà thuốc đạt chuẩn GPP tại Tỉnh Vĩnh Phúc.

\subsection{Phương pháp nghiên cứu}

2.2.1. Các biến số nghiên cứu:được xác định dựa vào bô checklist trong Thông tư số 02/2018/TT-BYT và Cẩm nang thực hành tốt nhà thuốc [2], [3].

2.2.2. Thiết kết nghiên cứu: Thiết kế nghiên cứu mô tả cắt ngang.

2.2.3. Cỡ mẫu nghiên cứu:

- Phỏng vấn người mua thuốc: gồm 228 người mua thuốc, phỏng vấn trực tiếp trung bình từ 8 đến 10 người mua thuốc/nhà thuốc tại 30 nhà thuốc ngẫu nhiên.

+ Tiêu chuẩn lựa chọn khách hàng mua thuốc:Khách hàng sau khi mua thuốc và đồng ý tham gia trả lời phỏng vấn; Khách hàng có khả năng trả lời câu hỏi, $\geq 18$ tuổi, không khiếm khuyết thính giác, thị giác, giọng nói.

+ Tiêu chuẩn loại trừ: Khách hàng không đồng ý tham gia vào nghiên cứu; Khách hàng chỉ mua một số loại vật tư y tế thông thường: bông, băng dán, cồn, gạc, khẩu trang y tế.

\subsubsection{Phương pháp thu thập số liệu}

Phương pháp phỏng vấn: Sử dụng bộ câu hỏi in sẵn để phỏng vấn trực tiếp người mua thuốc với nội dung đã được định hướng, ghi nhận cách xử lý của người bán thuốc, thu thập các thông tin liên quan đến việc chấp hành qui chế chuyên môn dược, hoat động bán lẻ (Hỏi - Khuyên - Tư vấn) của người bán thuốc thông qua dịch vụ họ cung cấp.

\section{KẾT QUẢ NGHIÊN CỨU}

Qua khảo sát tiến hành trên 30 nhà thuốc, thu được 228 phiếu phỏng vấn người mua thuốc, trong đó có 69 trường hợp mua thuốc có đơn, và 159 trường hợp mua thuốc không có đơn.

\section{Bảng 1. Nội dung người bán thuốc (NBT) đã hỏi khách hàng}

\begin{tabular}{|c|c|c|c|c|c|c|}
\hline \multirow{2}{*}{$\begin{array}{l}\text { Nội dung người bán thuốc (NBT) } \\
\text { hỏi khách hàng mua thuốc }\end{array}$} & \multicolumn{2}{|c|}{$\begin{array}{l}\text { KH được phỏng } \\
\text { vấn } n=228\end{array}$} & \multicolumn{2}{|c|}{$\begin{array}{l}\text { Khách hàng có } \\
\text { đơn thuốc }\end{array}$} & \multicolumn{2}{|c|}{$\begin{array}{l}\text { Khách hàng } \\
\text { không có đớn }\end{array}$} \\
\hline & $\begin{array}{c}\text { SL KH } \\
\text { được hỏi }\end{array}$ & $\begin{array}{l}\text { Tỉ lệ \% } \\
\text { n=228 }\end{array}$ & $\begin{array}{c}\text { SL KH } \\
\text { được hỏi }\end{array}$ & $\begin{array}{c}\text { Tỉ lệ \% } \\
n=69\end{array}$ & $\begin{array}{c}\text { SL KH } \\
\text { được hỏi }\end{array}$ & $\begin{array}{l}\text { Tỉ lệ \% } \\
n=159\end{array}$ \\
\hline Người bán thuốc (NBT) hỏi về đơn thuốc & 59 & 25,9 & 36 & 52,2 & 23 & 14,5 \\
\hline $\begin{array}{l}\text { NBT hỏi các nội dung đế kiếm tra đơn } \\
\text { thuốc trước khi bán }\end{array}$ & 23 & 10,1 & 23 & 33,3 & 0.00 & 0,0 \\
\hline NBT hỏi về đối tượng dùng thuốc & 166 & 72,8 & 43 & 62,3 & 123 & 77,4 \\
\hline $\begin{array}{l}\text { NBT hỏi về các triệu chứng bệnh, tình } \\
\text { trạng người bệnh }\end{array}$ & 169 & 74,1 & 26 & 37,7 & 143 & 89,9 \\
\hline NBT hỏi về thuốc đang sử dụng & 59 & 25,9 & 16 & 23,2 & 43 & 27,0 \\
\hline $\begin{array}{c}\text { NBT hỏi vê các bệnh đã và đang mắc } \\
\text { phải }\end{array}$ & 82 & 36,0 & 13 & 18,8 & 69 & 43,4 \\
\hline NBT hỏi về tiền sử dị ứng thuốc & 62 & 27,2 & 10 & 14,5 & 52 & 32,7 \\
\hline Không hỏi gì & 28 & 12,3 & 9 & 13,0 & 19 & 11,9 \\
\hline
\end{tabular}

Nhân xét: Kết quả cho thấy, phần lớn người bán thuốc đưa ra các câu hỏi tâp trung về đối tượng dùng thuốc (chiếm $72,8 \%$ ), yêu cầu khách hàng mô tả về các triệu chứng bệnh, tình trạng bệnh (chiếm $74,1 \%$ ). Bên cạnh đó các câu hỏi về đơn thuốc và kiểm tra đơn thuốc còn chiếm tỷ lệ khá thấp $(25,9 \%$ và $10,1 \%)$.

Bảng 2. Nội dung người bán thuốc (NBT) đã tư vấn cho khách hàng

\begin{tabular}{|c|c|c|c|c|c|c|}
\hline \multirow{2}{*}{$\begin{array}{l}\text { Nội dung người bán thuốc (NBT) tur } \\
\text { vấn khách hàng mua thuốc }\end{array}$} & \multicolumn{2}{|c|}{$\begin{array}{l}\text { KH được phỏng } \\
\text { vấn } n=228\end{array}$} & \multicolumn{2}{|c|}{$\begin{array}{l}\text { Khách hàng có } \\
\text { đơn thuốc }\end{array}$} & \multicolumn{2}{|c|}{$\begin{array}{l}\text { Khách hàng } \\
\text { không có đơn }\end{array}$} \\
\hline & \begin{tabular}{|c|} 
SL KH \\
được hỏi
\end{tabular} & $\begin{array}{l}\text { Tỉ lệ \% } \\
\text { n= 228 }\end{array}$ & \begin{tabular}{|c|} 
SL KH \\
được hỏi
\end{tabular} & $\begin{array}{c}\text { Tỉ lệ \% } \\
n=69\end{array}$ & \begin{tabular}{|c|} 
SL KH \\
được hỏi
\end{tabular} & $\begin{array}{l}\text { Tỉ lệ \% } \\
n=159\end{array}$ \\
\hline NBT & 27 & 11,8 & 6 & 8,7 & 21 & 13,2 \\
\hline & 142 & 62,3 & 23 & 33,3 & 119 & 74,8 \\
\hline NBT tư vấ & 54 & 23,7 & 8 & 11,6 & 46 & 28,9 \\
\hline NBT lựa chọn thuốc phù hợp với khả & 119 & 52,2 & 23 & 33,3 & 96 & 60,4 \\
\hline
\end{tabular}




\begin{tabular}{|c|c|c|c|c|c|c|}
\hline năng tài chính của KH & & & & & \\
\hline $\begin{array}{c}\text { NBT khuyên khi dùng thuốc có bất cứ } \\
\text { bất thường phải dừng và thông báo } \\
\text { ngay cho nhà thuốc }\end{array}$ & 52 & 22,8 & 9 & 13,0 & 43 & 27,0 \\
\hline $\begin{array}{c}\text { NBT tư vẫn điều chỉnh về chế độ sinh } \\
\text { hoạt, dinh dưỡng }\end{array}$ & 115 & 50,4 & 27 & 39,1 & 88 & 55,3 \\
\hline Không đưa ra lời tư vẫn gì & 22 & 9,6 & 9 & 13,0 & 13 & 8,2 \\
\hline
\end{tabular}

Nhận xét: Kết quảcho thấy các nội dung được người bán thuốc tư vấn nhiều nhất về cách phòng tránh bệnh (chiếm 62,3\%) và tư vấn về lựa chọn thuốc phù hợp với khả năng tài chính của khách hàng (chiếm 52,2\%); tư vấn điều chỉnh về chế độ sinh hoạt, dinh dưỡng (chiếm 50,4\%). Các tư vấn khác được đưa ra ít hơn như: $11,8 \%$ tư vấn nên đi khám bác sỹ; $23,7 \%$ tư vấn đổi thuốc, dùng thuốc mới; 22,8\% tư vấn khi dùng thuốc nếu có bất cứ bất thường phải dừng và thông báo ngay cho nhà thuốc. Đặc biệt có 9,6\% người bán thuốc không đưa ra sự tư vấn nào cho khách hàng.

Bảng 3. Nội dung người bán thuốc đã hướng dẫn người mua về cách sử dụng

\begin{tabular}{|c|c|c|c|c|c|c|}
\hline \multirow{2}{*}{$\begin{array}{c}\text { Nội dung người bán thuốc(NBT) } \\
\text { hướng dấn khách hàng cách sử } \\
\text { dụng }\end{array}$} & \multicolumn{2}{|c|}{$\begin{array}{l}\text { KH được phỏng } \\
\text { vấn } n=228\end{array}$} & \multicolumn{2}{|c|}{$\begin{array}{l}\text { Khách hàng có } \\
\text { đơn thuốc }\end{array}$} & \multicolumn{2}{|c|}{$\begin{array}{l}\text { Khách hàng } \\
\text { không có đơn }\end{array}$} \\
\hline & $\begin{array}{c}\text { SL KH } \\
\text { được hỏi }\end{array}$ & $\begin{array}{l}\text { Tỉ lệ \% } \\
\text { n= } 228\end{array}$ & $\begin{array}{c}\text { SL KH } \\
\text { được hỏi }\end{array}$ & $\begin{array}{c}\text { Tỉ lệ \% } \\
n=69\end{array}$ & $\begin{array}{c}\text { SL KH } \\
\text { được hỏ }\end{array}$ & $\begin{array}{l}\text { Tỉ lệ \% } \\
n=159\end{array}$ \\
\hline $\begin{array}{l}\text { NBT hướng dân cách sử dụng các } \\
\text { thuốc cho BN }\end{array}$ & 178 & 78,1 & 43 & 62,3 & 135 & 84,9 \\
\hline NBT hướng dân về thời điếm dùng thuốc & 182 & 79,8 & 39 & 56,5 & 143 & 89,9 \\
\hline $\begin{array}{l}\text { NBT thông tin về: tác dụng phụ, } \\
\text { tương tác thuốc, cânh báo của thuốc.. }\end{array}$ & 94 & 41,2 & 23 & 33,3 & 71 & 44,7 \\
\hline $\begin{array}{l}\text { NBT viết hướng dân sứ dưng thuốc } \\
\text { lên hốp/ vỉ thuốc }\end{array}$ & 180 & 78,9 & 48 & 69,6 & 132 & 83,0 \\
\hline Không hướng dân gì & 17 & 7,5 & 4 & 5,8 & 13 & 8,2 \\
\hline
\end{tabular}

Nhân xét: Nhìn chung hầu hết các nhà thuốc đã hướng dẫn khách hàng dùng thuốc. Có $78,1 \%$ lời hướng dẫn cách sử dụng thuốc cho bệnh nhân, 79,8\% hướng dẫn về thời điểm dùng thuốc, $78,9 \%$ viết hướng dẫn sử dụng thuốc lên hộp/vỉ. Tuy nhiên chỉ có $41,2 \%$ thông tin cho khách hàng về tác dụng phụ, tương tác thuốc, cảnh báo của thuốc, đặc biệt có $7,5 \%$ không hướng dẫn gì.

Bảng 4. Lý do khách hàng lựa chọn nhà thuốc để mua thuốc

\begin{tabular}{|c|c|c|c|}
\hline $\begin{array}{c}\text { Lí do khách hàng chọn nhà thuốc này để } \\
\text { mua thuốc }\end{array}$ & Số lượng & $\begin{array}{c}\text { Tổng số nhà } \\
\text { thuốc khảo sát }\end{array}$ & $\begin{array}{c}\text { Tỉ lệ \% } \\
\text { (n= 228) }\end{array}$ \\
\hline Nhà thuốc ở gần nhà & 124 & 228 & 54,4 \\
\hline Nhà thuốc nằm trên đường đi làm, đi học về. & 76 & 228 & 33,3 \\
\hline Nhà thuốc gần bệnh viện, nơi khám bệnh & 63 & 228 & 27,6 \\
\hline Người bán thuốc tứ vấn tốt & 142 & 228 & 62,3 \\
\hline Nhà thuốc nối tiếng trong khu vực & 98 & 228 & 43,0 \\
\hline
\end{tabular}

Bảng 5. Đánh giá của khách hàng về dịch cụ họ được cung cấp

\begin{tabular}{|c|c|c|c|}
\hline $\begin{array}{c}\text { Đánh giá của khách hàng về hoạt động tư } \\
\text { vấn của người bán }\end{array}$ & Số lượng & $\begin{array}{c}\text { Tống số nhà } \\
\text { thuốc khảo sát }\end{array}$ & $\begin{array}{c}\text { Tỉ lệ \% } \\
\text { (n= 228) }\end{array}$ \\
\hline $\begin{array}{c}\text { Người bán thuốc (NBT) có thái độ vui vẻ, niềm } \\
\text { nỡ khi tiếp xúc }\end{array}$ & 209 & 228 & 91,7 \\
\hline $\begin{array}{c}\text { NBT nhiệt tình, có kỹ năng giao tiếp tốt } \\
\text { NBT đã lựa chọn các thuốc phù hợp với nhu cầu } \\
\text { điều trị của anh/chị }\end{array}$ & 198 & 228 & 86,8 \\
\hline NBT có chuyên môn, tư vấn tốt & 194 & 228 & 100,0 \\
\hline NBT dường như không sắn sàng giúp đỡ & 0 & 228 & 85,1 \\
\hline
\end{tabular}

\section{BÀN LUÂN}

Hoạt động hỏi khách hang. Thông qua kết quả phỏng vấn trực tiếp người mua thuốc cho thấy phần lớn người bán thuốc đưa ra các câu hỏi tập trung về đối tượng dùng thuốc (chiếm
$72,8 \%$ ), yêu câu khách hàng mô tả về các triệu chứng bệnh, tình trạng bệnh (chiếm 74,1\%). Bên cạnh đó các câu hỏi về đơn thuốc và kiểm tra đơn thuốc còn chiếm tỷ lệ khá thấp (25,9\% và $10,1 \%)$. Việc khai thác các thông tin khác của khách hàng cũng vẫn hạn chế, 25,9\% khách 
hàng được hỏi về các thuốc đang sử dụng. Đa số khách hàng đều chỉ nhận được từ 2 đến 3 câu hỏi, cho thấy với lượng câu hỏi còn hạn chế, người bán thuốc chưa đủ để khai thác các thông tin quan trọng liên quan đến các triệu chứng để chẩn đoán bệnh và làm căn cứ để bán thuốc phù hợp, an toàn, hiệu quả.

Trường hợp bán có đơn thuốc, 52,2\% các nhà thuốc hỏi về đơn thuốc trước khi bán, và $33,3 \%$ kiểm tra đơn. Trong khi với trường hợp không đơn, tỉ lệ này còn thấp hơn, ở mức $(14,5 \%)$, như vậy có thể thây việc tuân thủ bán thuốc theo đơn chưa được chấp hành một cách nghiêm chỉnh.

Đa số các câu hỏi tập trung vào nội dung đối tượng dùng thuốc (chiếm 62,3\%) và các triệu chứng bệnh $(37,7 \%)$, rất ít các câu hỏi về các thuốc đang sử dụng (chiếm 23,2\%), các bệnh mắc phải (chiếm 18,8\%). Điều này cũng đã được phản ánh tương tự với một số nghiên cứu tại tỉnh Bà Rịa-Vũng Tàu [7] và thành phố Cần Thơ [5].

Với trường hợp khách hàng không có đơn thuốc, người bán thuốc hỏi nhiều hơn. Nội dung hỏi các triêuu chứng bệnh (lần lượt là $89,9 \%$ và $37,7 \%$ ), về các bệnh mắc phải (lần lượt là $43,4 \%$ và $18,8 \%)$, về tiền sử dị ứng thuốc $(32,7 \%$ và $14,5 \%)$. Điều này cho thấy ở trường hợp không đơn thuốc, người bán thuốc có xu hướng đưa ra nhiều câu hỏi hơn so với trường hợp có đơn. Tuy nhiên, có tới $12 \%$ khách hàng khổng nhận được lời hỏi nào, điều này hết sức nguy hiểm với người bệnh khi mua thuốc về nhà tự điều trị, đặc biệt là đối với những thuốc kê đơn, cần phải có sự thăm khám và chỉ định của bác sỹ.

Hoạt động tư vấn cho khách hang. Qua kết quả phỏng vấn 228 khách hàng, có $11,8 \%$ được tư vấn nên đi khám bác sỹ, tư vấn nhiều nhất về cách phòng tránh bệnh (chiếm 62,3\%) và tư vấn về lựa chọn thuốc phù hợp với khả năng tài chính của khách hàng (chiếm 52,2\%); tư vấn điều chỉnh về chế độ sinh hoạt, dinh dưỡng (chiếm 50,4\%). Các tư vấn khác được đưa ra ít hơn như: $11,8 \%$ tư vấn nên đi khám bác sỹ; $23,7 \%$ tư vấn đổi thuốc, dùng thuốc mới; $22,8 \%$ tư vấn khi dùng thuốc nếu có bất cứ bất thường phải dừng và thông báo ngay cho nhà thuốc. Đặc biệt có $9,6 \%$ người bán thuốc không đưa ra sự tư vấn nào cho khách hàng. Như vậy người bán thuốc đều đã đưa ra sự tư vấn cho khách hàng, nhưng tỷ lệ chưa cao.

Với trường hợp có đơn thuốc, 8,7\% người bán thuốc tư vấn nên đi khám bác sỹ, 33,3\% tư vấn về cách phòng tránh bênh, $11,6 \%$ tư vấn đổi thuốc, dùng thuốc mới, 33.3\% tư vấn khách hàng lựa chọn thuốc phù hợp với khả năng tài chính, $13 \%$ tư vấn cần phải thông báo ngay cho nhà thuốc khi có bất thường, 39,1\% tư vấn về chế độ sinh hoạt, dinh dưỡng; và đặc biệt có $13 \%$ trường hợp khồng đưa ra bất kì sự tư vấn nào.

Với trường hợp khách hàng mua thuốc không có đơn, đa số tỉ lệ các câu hỏi đưa ra đều cao hơn so với trường hợp mua thuốc có đơn, cụ thể: có $13,2 \%$ tư vấn đi khám bác sỹ, $74,8 \%$ tư vấn về cách phòng tránh bệnh, $28,9 \%$ tư vấn nên đổi thuốc, dùng thuốc mới, $60,4 \%$ thông báo và tư vấn lựa chọn thuốc phù hợp với tài chính của khách hàng, $27 \%$ khuyên nên thông báo cho nhà thuốc khi có bất thường xảy ra, $55,3 \%$ tư vấn về chế độ dinh dương, sinh hoạt, $8,1 \%$ không đưa ra bất kì sự tư vấn nào.

Điều này cho thấy sự tư vấn của người bán thuốc tập trung về cách phòng tránh bệnh, chế độ dinh dưỡng, và lựa chọn thuốc phù hợp với khả năng tài chính của khách hàng. Trong đó ở nội dung tư vấn về cách phòng tránh bệnh, trường hợp không có đơn (chiếm 74,8\%) cao hơn hẳn so với trường hợp có đợn (chiếm 33,3\%).

Hoạt động hướng dẫn sử dụng thuốc. Nhìn chung các nhà thuốc đã hướng dẩn khách hàng dùng thuốc khá tốt, đây là khâu được người bán thuốc thực hiện tốt nhất, đa số ở ngưỡng $80 \%$. Có $78,1 \%$ lời hướng dẩn cách sử dung thuốc cho bênh nhân, $79,8 \%$ hướng dẫn về thời điểm dùng thuốc, 78,9\% viết hướng dẫn sử dụng thuốc lên hộp/vì. Các nghiên cứu ở Hà Nội [4] và Hải Dương [1] cũng chỉ ra tương tự. Tuy nhiên chỉ có $41,2 \%$ thông tin cho khách hàng về tác dụng phụ, tương tác thuốc, cảnh báo của thuốc, đặc biệt có $7,5 \%$ không hướng dẫn gì.

Với trường hợp khách hàng có đơn, có tới 62,3\% người bán thuốc đã hướng dẫn sử dụng thuốc cho bệnh nhân, có $56,5 \%$ hướng dẫn về thời điểm dùng thuốc, $33.33 \%$ thông tin về tác dụng phụ, tương tác thuốc, cảnh báo thuốc, $69,6 \%$ viết hướng dẫn thuốc lên hộp/vỉ. Đặc biệt có $5,8 \%$ không hướng dẫn gì. Trong khi, với trường hợp khách hàng không có đơn thuốc, tất cả các nội dung người mua được hỏi đều có tần suất cao hơn so với trường hợp có đơn thuốc, cụ thể: có $84,9 \%$ người bán thuốc đã hướng dẫn sử dưng thuốc cho bệnh nhân, có $89,9 \%$ hướng dấn về thời điểm dùng thuốc, $46,6 \%$ thông tin về tác dụng phụ, tương tác thuốc, cảnh báo thuốc, $83 \%$ viết hướng dẫn thuốc lên hộp/vỉ. Đặc biệt có $8,2 \%$ không hướng dẫn gì.

Có thể thấy ở hoạt động hướng dẫn sử dụng thuốc, đa số người bán thuốc đều thực hiện, tập trung chủ yếu vào hoạt động hướng dẫn về thời 
điểm dùng thuốc, hướng dẫn cách sử dụng thuốc, viết HSDH lên hộp/ vỉ.

Về lý do khách hàng lựa chọn nhà thuốc. Đa số khách hàng lựa chọn nơi mua thuốc mà mình tin tưởng, chất lượng tốt, thuận tiện về giao thông. Điều này được thể hiện, cụ thể: $62,3 \%$ lựa chọn mua thuốc tại nhà thuốc tư vấn tốt, 54,4\% lựa chọn mua thuốc ở gần nhà. Bên cạnh đó, có $33,3 \%$ lựa chọn mua thuốc tại nhà thuốc nằm trên đường đi làm, đi học về; $27,6 \%$ mua tại nhà thuốc gần bênh viện, và $43 \%$ mua thuốc tại các nhà thuốc nổi tiếng ở khu vực.

Nhận xét của khách hàng về dịch vụ họ được cung cấp. Nhìn chung, khách hàng đều hài lìng về thái độ phục vụ cũng như chất lượng mà họ được cung cấp, có $91,7 \%$ cho rằng người bán thuốc có thái độ vui vẻ, niềm nở khi tiếp xúc, $86,8 \%$ người bán thuốc nhiệt tình, có kỹ năng giao tiếp tốt, $100 \%$ cho rằng đã lựa chọn các thuốc phù hợp với nhu cầu điều trị, $85,1 \%$ cho rằng người bán thuốc có chuyên môn, tư vấn tốt.

\section{KẾT LUẦ}

Nghiên cứu cho thãy, đa số khách hàng đều nhận được ít câu hỏi từ người bán thuốc. Nngười bán thuốc chưa khai thác các thông tin quan trọng liên quan đến các triệu chứng để chẩn đoán bệnh và làm căn cứ để bán thuốc phù hợp, an toàn, hiệu quả. Hoạt động tư vấn khách hàng được thực hiện khá đầy đủ, nhưng tỷ lệ chưa cao. Hoạt động hướng dẫn sử dụng thuốc được đa số người bán thuốc thực hiện với tỉ lệ và tuần xuất cao nhất. Đối với các trường hợp khách hàng không có đơn thuốc, các hoạt động hỏi tư vấn - hướng dẫn có tî lệ cao hớn với trường hợp khách hàng có đơn.

\section{TÀI LIÊUU THAM KHẢO}

1. Nguyễn Thị Kim Anh (2016), Phân tích hoạt động của các nhà thuốc trên địa bàn thành phố Hải Dương, Luân văn Thạc sĩ Dược học, Trương Đai học Dược Hà Nội.

2. Bồ Y Tế (2010), Cẩm nang thực hành tốt nhà thuốc, Nhà xuất bản Y Học, Hà Nội.

3. Bố Y' Tế (2018), Thông tư số 02/2018/TT-BYT ngày $22 / 01 / 2018$ Quy định về thực hành tốt cơ sở bản lẻ thuốc.

4. Dương Thanh Huyên (2019), Phân tích viêc thực hiện tiêu chuẩn thực hành tốt cơ sở bán lẻ thuốc đối với nhà thuốc trên địa bàn Quâan Hoàn Kiếm thành phố Hà Nội năm 2018, Luận văn Thạc sĩ Dược học, Trường Đại học Dược Hà Nội.

5. Nguyễn Dieẹu Linh (2017), Đánh giá hoạt động hành nghề của các quầy thuốc đạt Tiêu chuẩn thực hành tốt nhà thuốc tai thành phố Cần Thơ năm 2017, Luận văn thạc sî dược học, Trường Đại học Dước Hà Nội.

6. Sở Y tế Tỉnh Vình Phúc (2019), Báo cáo tổng kết công tác Dược năm 2018-2019,

7. Đặng Thị Thanh Y (2019), Đánh giá thực trạng hoạt động của các nhà thuốc đạt tiêu chuẩn GPP tại Tính Bà Rịa-Vũng Tàu năm 2018, Luận văn Dược sỹ chuyên khoa cấp II, Trường Đại học Dược Hà Nội.

\section{ĐÁNH GIÁ KẾT CỰC Ở BÊNH NHÂN XUẤT HUYÊTT DƯỚI NHỆN DO VÕ̃ PHİNH ĐộNG MẠCH NÃO ĐƯợC ĐIỀU TRI CAN THIỆP NỘI MACH}

\section{Tạ Vương Khoa', Vũ Anh Nhị ${ }^{2}$, Nguyễn Quang Trí ${ }^{3}$ Phan Đình Văñ1, Phí Ngọc Dương ${ }^{1}$}

\section{TÓM TẮT}

Đặt vấn đề: Các hướng dẫn quốc tế cũng như các quy trình trong nước mới nhất hiện nay về can thiệp nôi mạch điêu tri xuất huyết dưới nhên do võ phình động mạch não đã có sự cập nhật và điều chỉnh trong vài năm gần đây. Đánh giá hiệu quả của các quy trình đang lưu hành trong nước là cần thiết. Mục tiêu: Xác định tî lệ tử vong, tử vong và tàn phế ở bệnh nhân

\footnotetext{
${ }^{1}$ Bệnh viện Quân y 175

¿Đại họ Y Dượ TPHCM

33ệnh viện Nhân Dân 115

Chịu trách nhiệm chính: Tạ Vương Khoa

Email: drvuongkhoa@yahoo.com

Ngày nhận bài: 3.3.2021

Ngày phản biện khoa học: 26.4.2021

Ngày duyệt bài: 11.5.2021
}

xuất huyết dưới nhện do võ phình động mạch não được điểu trị can thiệp nội mạch tại Bệnh viện Nhân Dân 115 tại thời điểm xuất viện và thời điểm 1 năm. Đối tượng và phương pháp nghiên cứu: Nghiên cứu theo dõi tiến cứu dọc trên 108 bệnh nhân xuất huyết dưới nhện do vỡ túi phình động mạch não được điêuu trị can thiệp nội mạch nút túi phình bằng vòng xoắn kim loại tại Bệnh viện Nhân Dân 115 từ tháng 10/2018 đến tháng 4/2020. Kết quả: Tuổi trung bình của dân số nghiên cứu là $52,8 \pm 12,7$. Tỉ lệ nam/nữ là $1 / 1$. Tỉ lệ tử vong, tử vong và tàn phế tại thời điểm xuất viện lần lượt là $3,7 \%$ và $18,5 \%$, tại thời điểm 1 năm lần lượt là 3,7\% và 13,9\%. Kết luận: Can thiệp nội mach theo quy trình đang lưu hành là lựa chọn hiệu quả trong điêuu trị xuất huyết dưới nhện do võ phình động mạch não tai Bệnh viện Nhân dân 115.

Tư khóa: xuất huyết dưới nhện do võ phình động mạch não, can thiệp nội mạch, kết cục 